\title{
Effects of different groundcover matters on nutrient availability in an integrated apple orchard in Eastern-Hungary
}

\author{
Péter Tamás Nagy \\ Department of Agricultural Chemistry and Soil Science, Centre for Agricultural and Applied Economic Sciences, University of Debrecen, \\ nagypt@agr.unideb.hu
}

Keywords: groundcover, apple, nutrition management, plant uptake

SUMMARY

\begin{abstract}
The aim of our study is to examine the effects of different groundcover methods on nutrient availability and uptake of apple orchard. The experiment was carried out at the orchard of TEDEJ Rt. at Hajdúnánás-Tedej, in Eastern Hungary. The orchard was set up on lowland chernozem soil in the Nyírség region. It was established in the autumn of 1999, using Idared cultivar grafted on MM106 rootstocks at a spacing of $3.8 \times 1.1 \mathrm{~m}$.

The applied treatments were divided into two groups according to origins and effects. On the one hand, different livestock manures (cow, horse and pig), on the other hand different mulch-matters (straw, pine bark mulch, black foil) were used. The different manures and mulches were applied on the surface to test the effectiveness of these materials.

The effectiveness of manure treatments was higher than the other treatments on AL soluble $\mathrm{P}$ content of soil. Mostly the manure treatments increased the AL soluble $\mathrm{K}$ of soil. Our all treatments increased $0.01 \mathrm{M} \mathrm{CaCl}_{2}$ soluble $\mathrm{NO}_{3}^{-}-\mathrm{N}$ content of the examined soil layers. The effect of manure treatments was the highest. From the results it was evident that the amount of easily soluble organic nitrogen fraction distributed more homogeneously than the other mineral $\mathrm{N}$ fractions examined.

Our results can be summarized as follows:

1. Our results pointed out that the used ground covering matters divided into several categories regarding its effect.

2. The available N, P and $\mathrm{K}$ contents of soil were mostly increased by applying manures.

3. The effectiveness of straw, mulch and mostly black foil was lower.

4. Differences were found between nutrient supplying treatments and the treatments which did not supply nutrients.
\end{abstract}

\section{INTRODUCTION}

In the last few decades the anthropogenic contamination of our soils has continuously increased. Urgent task of recent days is to prevent further degradation of soils and improve the ecological characteristics of soils (Kincses et al., 2008; Sipos et al., 2009; Sipos, 2009).

According this statement, the importance of ground covering techniques has increased in the last few decades owing to their application in organic farming (Skroch and Shribbs, 1986). Moreover, they are regarded as excellent water saving methods (Merwin et al., 1994).

Mulching has several benefits which were summarized by Merwin et al., (1994). Mulches are not only highly effective in checking evaporation and weed control, but also have influences on several processes in the soil. The benefits are variously attributed to the suppression of weed growth, to the conservation of moisture by reducing evaporation and run off, to protection from erosion, to increased infiltration of water, to the increase or decrease of soil-temperature fluctuations, to the enhancement of mineral nutrient availability, to the enhancement of nitrification, to additional nutrients and organic matter derived from a decomposing mulch, or to the preservation or improvement of soil structure. Moreover, mulching has a positive effect on nutritional and biological factors as well.

On the one hand, mulching causes an increase in the nutrient content of the soil as water leaches nutrients out of the mulch. However, the entire condition of nutrient availability may be modified for better or worse by changes induced in the moisture and temperature regimes of the soil. On the other hand, applying mulches increases root length density and brings the roots closer to the surface (Merwin and Stiles, 1994). Moreover, mulching enhances apple fruit storage quality (Lang et al., 2001).

Several publications pointed out that mulching has a positive effect on the water and temperature regimes of soil and it involves nutritional and biological factors as well.

Nowadays the number of irregular climatic anomalies is growing due to the global climatic change. It is very important that the productivity and the available nutrient supply of soil should be improved under these climatic conditions.

Based on the study of Merwin et al., (1994) and Merwin and Stiles (1994) mulching seems as an effective tool to achieve the above mentioned goals mostly in organic production systems where the possible nutritional tools are restricted and the consumer demands are high.

The importance of groundcover management is intensified by the decrease of available soil moisture and frequent drought events.

Although, the practice of mulching is well known to horticulture, there is a little information about its application and its effects on orchard nutritional management, especially in Central Europe and Hungary. Therefore, the aim of the present paper is to study the effects of different groundcover methods on nutrient availability and uptake of apple orchard. 


\section{MATERIALS AND METHODS}

The experiment was carried out at the orchard of TEDEJ Rt. at Hajdúnánás-Tedej, in Eastern Hungary. The orchard was set up on lowland chernozem soil in the Nyírség region. It was established in the autumn of 1999, using Idared cultivar grafted on MM106 rootstocks at a spacing of $3.8 \times 1.1 \mathrm{~m}$. Each plot consisted of 10 trees. The orchard has been treated according to the Integrated Fruit Production guidelines. The orchard has an irrigation system, which is applied if the weather conditions require, but in 2005 the sampling site was not irrigated due to the sufficient rainfall. Soil samples were taken from three layers $(0-20 \mathrm{~cm} ; 20-40 \mathrm{~cm}$ and $40-60$ $\mathrm{cm}$ ) of each plot, from the middle of the section by using manual soil sampling equipment. Sampling was performed at the beginning of the vegetation period, in April, 2005, before applying groundcover matters. For the characterisation of the soil the most important soil parameters and nutrient status were determined. The applied treatments of the examined orchard part are indicated in Table 1. Our treatments were divided into two groups according to their origins and effects. On the one hand, different livestock manures, on the other hand different mulch-matters were used. The used manures and mulches were applied on the surface to test the effectiveness of these materials. The layout of the groundcover matter was the same in all treatments. The line of trees was covered in $1.5 \mathrm{~m}$ wide stripes along plots. So the covered area was $16.5 \mathrm{~m}^{2}$.

Table 1.

\begin{tabular}{lc} 
& Applied treatments \\
\hline Treatments & Applied dose $\left(\mathbf{m}^{3} / \mathbf{p l o t}\right)$ \\
\hline Control & - \\
Straw & 2.475 \\
Pine bark mulch & 0.5 \\
Cow manure & 1.65 \\
Horse manure & 1.65 \\
Pig manure & 1.65 \\
Black foil & $0.5 \mathrm{~mm}$ (thickness) \\
\hline
\end{tabular}

The soil samples of 1-1.5 $\mathrm{cm}$ were dried outdoors. Before grinding, samples were cleaned from plant remains and other possible dirt, and the soil was sieved through a $2 \mathrm{~mm}$ screen, homogenized and stored in plastic boxes in dry place until the examination. The main characteristics of soil and the contents of macronutrients were measured by using two kinds of methods. For establishing the contents of easily soluble nutrient forms of $\mathrm{N}, \mathrm{P}$ and $\mathrm{K} 0.01 \mathrm{M} \mathrm{CaCl}_{2}$ extractant was used according to the method described by Houba et al., (1986). For studying the available $\mathrm{P}$ and $\mathrm{K}$ contents of soil the conventional extracting solution, $\mathrm{NH}_{4^{-}}$ lactate+acetic acid (so called AL extractant) was used according to the Hungarian standards.

\section{RESULTS AND DISCUSSION}

\section{1) The results of soil sampling before the treatments were set up}

The results of soil sampling before the treatments were set up are showed in Table 2 .

The $\mathrm{pH}$ of soil was near the neutral value, slightly alkaline. The physical category of soil was clay loam with major carbonate content. According to results of AL solution the P- and $\mathrm{K}$-supplies of the examined soil were in the "medium" range, but their amounts significantly decreased by depth. Soil $\mathrm{N}$ was sufficient based on humus content.

The values of $0.01 \mathrm{M} \mathrm{CaCl}_{2}$ soluble $\mathrm{N}$ forms correspond to the type of the examined soil. The presence of mineral nitrogen was represented mainly by nitrate-nitrogen form due to soil $\mathrm{pH}$. The nitrate and ammonium contents of soil were low and decreased according to depth, while the soluble organic nitrogen contents of soil were slightly different in the examined layers. It is notable that the amount of soluble organic nitrogen content of soil is commensurable with mineral $\mathrm{N}$ forms of soil. 
Results of soil sampling before treatments were set up

Table 2.

\begin{tabular}{|c|c|c|c|c|}
\hline \multirow[b]{2}{*}{ Parameters } & \multicolumn{4}{|c|}{ Depth $(\mathrm{cm})$} \\
\hline & $0-20$ & $20-40$ & $40-60$ & $0-60$ \\
\hline $\mathrm{pH}\left(\mathrm{CaCl}_{2}\right)$ & 7.43 & 7.36 & 7.54 & 7.44 \\
\hline $\mathrm{Hu} \%$ & 2.95 & 2.83 & 2.58 & 2.79 \\
\hline $\mathrm{K}_{\mathrm{A}}$ & & & & 45 \\
\hline \multirow[t]{2}{*}{$\mathrm{CaCO}_{3} \%$} & 8.30 & 8.50 & 12.50 & 9.77 \\
\hline & \multicolumn{4}{|c|}{$\mathrm{mg} / \mathrm{kg}$} \\
\hline $\mathrm{AL}-\mathrm{P}_{2} \mathrm{O}_{5}$ & 164.11 & 89.12 & 42.7 & 98.64 \\
\hline $\mathrm{AL}-\mathrm{K}_{2} \mathrm{O}$ & 263.93 & 160.69 & 88.65 & 171.09 \\
\hline $\mathrm{CaCl}_{2}-\mathrm{NO}_{3}-\mathrm{N}$ & 13.05 & 8.29 & 5.25 & 8.86 \\
\hline $\mathrm{CaCl}_{2}-\mathrm{NH}_{4}-\mathrm{N}$ & 1.05 & 0.76 & 0.19 & 0.67 \\
\hline $\mathrm{CaCl}_{2}$-Norg & 3.29 & 4.32 & 2.64 & 3.42 \\
\hline
\end{tabular}

2) The results of soil sampling after the treatments were set up

The results of AL soluble P of soil after the treatments were set up (autumn 2006) are shown in Table 3. All treatments applied increased the AL soluble P content of soil mostly in the upper layer compared to the control.

Effect of treatments on AL soluble $\mathrm{P}_{2} \mathrm{O}_{5}$ content of soil (2006)

Table 3.

\begin{tabular}{|c|c|c|c|}
\hline \multirow[b]{2}{*}{ Treatments } & \multicolumn{3}{|c|}{$\begin{array}{c}\mathrm{AL}-\mathrm{P}_{2} \mathrm{O}_{5}(\mathrm{mg} / \mathrm{kg}) \\
\text { Depth }(\mathrm{cm})\end{array}$} \\
\hline & $0-20$ & $20-40$ & $40-60$ \\
\hline Control & $113.24 \mathrm{a}$ & $35.90 \mathrm{a}$ & $28.91 \mathrm{a}$ \\
\hline Straw & $201.17 b$ & $245.02 \mathrm{e}$ & $44.33 \mathrm{~d}$ \\
\hline Pine bark mulch & $148.65 \mathrm{a}$ & $136.81 \mathrm{c}$ & $41.20 \mathrm{c}$ \\
\hline Cow manure & $262.61 d$ & $96.37 \mathrm{~b}$ & $27.71 \mathrm{a}$ \\
\hline Horse manure & $220.69 b$ & $172.74 \mathrm{c}$ & $27.47 \mathrm{a}$ \\
\hline Pig manure & $241.38 \mathrm{c}$ & $73.24 \mathrm{a}$ & $27.71 \mathrm{a}$ \\
\hline Black foil & $219.00 \mathrm{~b}$ & $99.50 \mathrm{~b}$ & $38.07 b \mathrm{c}$ \\
\hline Average & 200.96 & 122.80 & 33.63 \\
\hline
\end{tabular}

The effectiveness of manure treatments was higher than the other treatments. The AL soluble P content of soil was twice as much in these treatments as in the control. Nevertheless, the AL soluble P content of soil dramatically decreased according to the depth and between 40-60 cm, its amount reached the control level. This pointed out that immobile phosphate content of soil was affected only in the upper layer by surface application of mulches.

The results of AL soluble K of soil after the treatments were set up (autumn 2006) were shown in the Table 4.

Mostly the manure treatments increased the AL soluble $\mathrm{K}$ of soil. Its amount increased threefold in the upper layer of soil according to the high dose and high K content of manures. A more moderate effect was observed by applying black foil while the effectiveness of straw and mulch was between the manure and foil application.

The AL soluble K content of soil significantly decreased by depth, but the treatments also had an effect on the available $\mathrm{K}$ content of soil in the lower layers. 
Effect of treatments on AL soluble $\mathrm{K}_{2} \mathrm{O}$ content of soil (2006)

Table 4.

\begin{tabular}{lccc}
\hline \multicolumn{3}{c}{$\begin{array}{c}\text { AL-K } 2 \mathrm{O}(\mathrm{mg} / \mathrm{kg}) \\
\text { Depth }(\mathrm{cm})\end{array}$} \\
Treatments & $0-20$ & $20-40$ & $40-60$ \\
\hline Control & $173.52 \mathrm{a}$ & $108.95 \mathrm{a}$ & $72.63 \mathrm{a}$ \\
Straw & $318.78 \mathrm{~b}$ & $213.87 \mathrm{~d}$ & $129.13 \mathrm{~d}$ \\
Pine bark mulch & $302.64 \mathrm{~b}$ & $230.01 \mathrm{e}$ & $137.20 \mathrm{~d}$ \\
Cow manure & $585.11 \mathrm{e}$ & $169.48 \mathrm{c}$ & $92.81 \mathrm{~b}$ \\
Horse manure & $528.99 \mathrm{~d}$ & $189.66 \mathrm{c}$ & $100.88 \mathrm{~b}$ \\
Pig manure & $552.83 \mathrm{e}$ & $201.76 \mathrm{~d}$ & $104.92 \mathrm{c}$ \\
Black foil & $193.69 \mathrm{a}$ & $157.37 \mathrm{~b}$ & $84.74 \mathrm{a}$ \\
\hline Average & $\mathbf{3 7 9 . 3 7}$ & $\mathbf{1 8 1 . 5 9}$ & $\mathbf{1 0 3 . 1 9}$ \\
\hline
\end{tabular}

The results of $0.01 \mathrm{M} \mathrm{CaCl}_{2}$ soluble $\mathrm{NO}_{3}{ }^{-}-\mathrm{N}$ of soil after the treatments were set up (autumn 2006) are shown in the Table 5.

All treatments increased the $0.01 \mathrm{M} \mathrm{CaCl}_{2}$ soluble $\mathrm{NO}_{3}{ }^{-} \mathrm{N}$ content of the soil layers examined. The effect of manure treatments was the highest. Significant increasing was observed using horse and pig manures. The effects of mulching and foil covering were the smallest.

Table 5.

Effect of treatments on $0.01 \mathrm{M} \mathrm{CaCl}$ soluble $\mathrm{NO}_{3}^{-}-\mathrm{N}$ content of soil (2006)

\begin{tabular}{|c|c|c|c|}
\hline \multirow[b]{2}{*}{ Treatments } & \multicolumn{3}{|c|}{$\begin{array}{c}\mathrm{NO}_{3}^{-}-\mathrm{N}(\mathrm{mg} / \mathrm{kg}) \\
\text { Depth }(\mathrm{cm})\end{array}$} \\
\hline & $0-20$ & $20-40$ & $40-60$ \\
\hline Control & $2.01 \mathrm{a}$ & $0.72 \mathrm{a}$ & $0.40 \mathrm{a}$ \\
\hline Straw & $7.23 b$ & $8.16 \mathrm{~d}$ & $10.16 \mathrm{~d}$ \\
\hline Pine bark mulch & $3.82 \mathrm{a}$ & $5.78 \mathrm{c}$ & $4.78 b$ \\
\hline Cow manure & $7.34 \mathrm{~b}$ & $6.26 \mathrm{c}$ & $10.65 d$ \\
\hline Horse manure & $14.60 \mathrm{~d}$ & $8.59 \mathrm{~d}$ & $7.51 \mathrm{c}$ \\
\hline Pig manure & $17.51 \mathrm{~d}$ & $10.18 \mathrm{e}$ & $11.90 \mathrm{~d}$ \\
\hline Black foil & $2.98 \mathrm{a}$ & $2.66 \mathrm{a}$ & $3.21 \mathrm{a}$ \\
\hline Average & 7.93 & 6.05 & 6.94 \\
\hline
\end{tabular}

The results of the $0.01 \mathrm{M} \mathrm{CaCl}_{2}$ soluble $\mathrm{NH}_{4}{ }^{+}-\mathrm{N}$ of soil after the treatments were set up (autumn 2006) are shown in the Table 6. Beside horse and pig manures, mulching also increased the easily soluble $\mathrm{NH}_{4}{ }^{+}-\mathrm{N}$ content of soil significantly. Moreover, the applied treatments increased the easily soluble $\mathrm{NH}_{4}{ }^{+}-\mathrm{N}$ content of soil to a lesser extent than the soluble $\mathrm{NO}_{3}{ }^{-}-\mathrm{N}$ content. This statement is especially true for the $\mathrm{NH}_{4}{ }^{+}-\mathrm{N}$ content of the upper soil layer. The $\mathrm{NH}_{4}{ }^{+}-\mathrm{N}$ content increased more significantly in deeper soil layers than the upper layers (Table 6).

Effect of treatments on $0.01 \mathrm{M} \mathrm{CaCl}{ }_{2}$ soluble $\mathrm{NH}_{4}{ }^{+}-\mathrm{N}$ content of soil (2006)

Table 6.

\begin{tabular}{lccc}
\hline \multicolumn{3}{c}{} & $\begin{array}{c}\mathrm{NH}_{4}{ }^{+}-\mathrm{N}(\mathrm{mg} / \mathrm{kg}) \\
\text { Depth }(\mathrm{cm})\end{array}$ \\
Treatments & $0-20$ & $20-40$ & $40-60$ \\
\hline Control & $2,53 \mathrm{a}$ & $0,91 \mathrm{a}$ & $3,70 \mathrm{a}$ \\
Straw & $3,90 \mathrm{~b}$ & $5,07 \mathrm{~d}$ & $1,57 \mathrm{a}$ \\
Pine bark mulch & $4,67 \mathrm{~b}$ & $6,61 \mathrm{e}$ & $4,44 \mathrm{~d}$ \\
Cow manure & $2,46 \mathrm{a}$ & $3,85 \mathrm{c}$ & $4,24 \mathrm{~d}$ \\
Horse manure & $4,98 \mathrm{~b}$ & $5,37 \mathrm{~d}$ & $3,51 \mathrm{c}$ \\
Pig manure & $8,34 \mathrm{e}$ & $3,41 \mathrm{~b}$ & $1,22 \mathrm{a}$ \\
Black foil & $1,94 \mathrm{a}$ & $2,03 \mathrm{a}$ & $\mathbf{2 , 6 9}$ \\
\hline Average & $\mathbf{4 , 1 2}$ & $\mathbf{3 , 8 9}$ & \\
\hline
\end{tabular}

The results of the $0.01 \mathrm{M} \mathrm{CaCl}_{2}$ soluble organic nitrogen fraction $\left(\mathrm{N}_{\mathrm{org}}\right)$ of soil after the treatments were set up (autumn 2006) are shown in the Table 7. 
Effect of treatments on 0.01M $\mathrm{CaCl}_{2}$ soluble $\mathrm{N}_{\text {org }}$ content of soil (2006)

Table 7.

\begin{tabular}{|c|c|c|c|}
\hline \multirow[b]{2}{*}{ Treatments } & \multicolumn{3}{|c|}{$\begin{array}{c}\text { Norg }(\mathrm{mg} / \mathrm{kg}) \\
\text { Depth }(\mathrm{cm})\end{array}$} \\
\hline & $0-20$ & $20-40$ & $40-60$ \\
\hline Control & $2,51 \mathrm{a}$ & $3,52 \mathrm{a}$ & $2,86 a$ \\
\hline Straw & $3,17 \mathrm{a}$ & $4,95 b$ & $3,79 a$ \\
\hline Pine bark mulch & $2,44 a$ & $4,95 \mathrm{~b}$ & $4,80 \mathrm{~b}$ \\
\hline Cow manure & $3,83 \mathrm{a}$ & $4,25 \mathrm{a}$ & $3,84 \mathrm{a}$ \\
\hline Horse manure & $3,40 \mathrm{a}$ & $3,66 \mathrm{a}$ & $3,91 \mathrm{a}$ \\
\hline Pig manure & $9,19 \mathrm{~d}$ & $8,10 \mathrm{e}$ & $7,92 \mathrm{e}$ \\
\hline Black foil & $3,31 \mathrm{a}$ & $3,97 \mathrm{a}$ & $3,85 \mathrm{a}$ \\
\hline Average & 3,55 & 4,77 & 4,42 \\
\hline$L S D_{5 \%}$ & 1,88 & 1,09 & 1,14 \\
\hline
\end{tabular}

A significant effect was observed at applying only pig manure. From the results it was evident that the easily soluble organic nitrogen fraction distributed more homogeneously than the other mineral $\mathrm{N}$ fractions. Its amount increased by the depth. The amount of this $\mathrm{N}$ fraction was considerable and comparable to mineralized $\mathrm{N}$ fractions.

\section{Conclusions}

Our results pointed out that the used ground covering matters divided into several categories regarding their effects.

The available N, P and K contents of soil were mostly increased by applying manures.

The effectiveness of straw, mulch and mostly black foil was lower.

Differences were found between nutrient supplying treatments and the treatments which did not supply nutrients.

\section{Acknowledgements}

Thanks to OM-00042/2008, OM-00265/2008 and OM-00270/2008 projects for financial assistance.

\section{REFERENCES}

Houba V.J.G., Novozamsky I., Huybregts A.W.M., J.J. van der Lee (1986): Comparison of soil extraction by 0.01M CaCl2 by EUF and by some conventional extraction procedures. Plant and Soil 96:433- 437.

Kincses Sándorné, Filep Tibor, Kátai János (2008): Szerves -, mủ - és baktériumtrágyázás hatása a talajok 0,01M $\mathrm{CaCl}_{2}$-oldható tápelemtartalmára Talajvédelem (különszám) 423-430.

Lang, A. - M. H. Behboudian, - J. Kidd, - H. Brown, 2001. Mulch enhances apple fruit storage quality. Acta Horticulturae 557. 433-439.

Merwin, I.A., W.C. Stiles, and H.M. van Es. (1994): Orchard groundcover management impacts on soil physical properties. J. Amer. Soc. Hort. Sci. 119:209-215.

Merwin, I.A., and W.C. Stiles. Orchard groundcover management impacts on apple tree growth and productivity, and soil nutrient availability and uptake (1994) J. Amer. Soc. Hort. Sci. 119:216-222.

Nagy P.T. (2000): Égetéses elven müködö elemanalizátor alkalmazhatósága talaj- és növényvizsgálatokban. Agrokémia és Talajtan 49. 3-4. 521-534.

Skroch W.A. and Shribbs J.M., (1986): Orchard floor management: an overview. HortScience 21: 390- 393.

Sipos, M., I. Kincses, E. Berta Szabó (2009): Study of the effect of limiting production factors - hybrid, nutrient-supply level and irrigation on the yield and starch-content of maize (Zea Mays L.). Cereal Research Communications 37: 145-148. (Suppl.)

Sipos M. (2009): A kukorica (Zea mays L.) termésének, valamint néhány beltartalmi értékének vizsgálata a hibrid, a tápanyag-ellátás és az öntözés függvényében. Agrokémia és Talajtan. 58. 1. 79-90. 